\title{
Genome complexity of begomovirus disease and a concern in agro-economic loss
}

\author{
Hanjabam Joykishan Sharma*, Susheel Kumar Sharma, Nongthombam Bidyananda Singh \\ Department of Plant Pathology, ICAR-NEH Region, Manipur Centre, Imphal, Manipur, India
}

ARTICLE INFO

Article history:

Received on: September 30, 2018

Accepted on: December 22, 2018

Available online: April 05, 2019

\section{Key words:}

Bemisia tabaci,

Begomovirus,

Agro-economic lost,

Pathogenicity,

CRISPR/cas9,

siRNA silencing,

Diversity

\section{ABSTRACT}

Significant agro-economic loss becomes a foremost concern in terms of productivity and feeding the expanding population. Among all plant pathogens, begomovirus is also one of the contagions which affect most monocot and dicots. Begomovirus is transmitted by the whitefly vector Bemisia tabaci and causes potential yield reduction in a number of economically important crops. The evolution of the new strain of begomovirus through genetic changes, climatic factors, and mutation drastically affects the agricultural yield and thus the economic loss. A strategic Begomo management would foster the healthier agricultural environment. The review focus on classification, genome organisation, replication, pathogenecity, phylogeny, genetic diversity, technology behind its suppression, concealment and kayo.

\section{INTRODUCTION}

Begomo is small obligate parasite having single-stranded DNA genome surrounded by viral encoded $10 \mathrm{KDa}$ proteins accountable for viral replication, assembly, host genetic regulation, vector transference, and silencing muffling [1]. Begomoviridae belongs to plant viral family Geminiviridae. The single-stranded DNA genome replicates by rolling circle mode of replication (RCR) assisted by host factors. Rep protein initiation and post-initiation have been studied extensively. Begomo can be monopartite and bipartite. Watermelon chlorotic stunt virus is wellknown typical bipartite [2]. The transmission was reported vindicate by whitefly Bemisia tabaci (Gennadius), leading to the extreme yield reduction of important agro-economic vegetable [3]. The virus infects different plant, namely tomato, okra, soybean, pepper, cotton, tobacco, watermelon, weed, beans, cassava, euphorbia, Cucurbitae, and Amaranthus. The alpha satellite and the beta satellite Begomo species about half the size of helper Begomo genome have been reported in plants infected by begomovirus [4]. Most varieties of northeastern state of India have been identified by different strains of Begomo. Stunted, distorted growth, chlorotic spot, leaf curling, golden yellow mosaic pattern, mottling leaves, and reduced yield were common symptoms investigated [5]. B. tabaci virulence vector infects the phloem cells of host

*Corresponding Author

Hanjabam Joykishan Sharma,

Department of Plant Pathology, ICAR-NEH Region,

Manipur Centre, Imphal, Manipur, India.

E-mail: jkshnshrm@gmail.com plant through phloem transport, the pathogenesis reaches the vascular and mesophyll cells. Begomo replicates by RCR using replication machinery of the host [6]. The B-biotype having greater host range and fecundity increases the transmission rate [7]. Plant viral defense strategies with the new revolutionary tools such as RNAi silencing, TALENS, ZFN, SmART, and CRISPR cas9 have been instigated.

\subsection{Genome Complexity of Begomo}

Delve into the viral genome and its imprinting biochemistry accord us the considerable organizational and functional aspects. Begomo have the most diverse complexity among all the subfamily of Geminivirus. Two components, DNA A and DNA B (MYMIV), complete the diverse genome. Sometimes, the satellite DNA beta has been reported in association with monopartite species [8-10]. DNAA and B show similarity in size $(2.7-3 \mathrm{~kb})$ but differ in the sequence except the common region (CR). A segment of CR called as intergenic region (IR) guide the onset of replication and promoter for transcription process. IR of Begomo has hairpin loop of nanonucleotide sequence TAATATTAC empowered for replication. Six or seven ORFs region encodes most coat protein (CP) of $10 \mathrm{KDa}$ size name as replication initiator (Rep), replication enhancer, and TrAP (silencing suppressor). BC1/NSP and BV1/MP were assisted as nucleo shuttle and viral movement protein, respectively [11]. Begomo viral replicates through RCR and DNA A component shows independent replication as compared to DNA B. MYMIV-DNA A have been studied extensively as a model for viral replication [12]. Two CP/V encodes for viral movement, transmission, and encapsidation (Sharma, Hanley 2009; Ikegami 2009), nicking the DNA that limits in viral copy number 
and pre-CP/V2 serve pathogenicity as well as the suppressor of RNAi silencing. Another $\mathrm{C} 4$ protein reported in case of bipartite begomovirus believes to have pathogenicity determinant factor and siRNA silencing suppression [Figures 1-3] [13].

\subsection{Transmission, Infection, and Replication of Begomovirus}

\subsubsection{Vector transmission}

An arthropod vector B. tabaci was responsible for plant-to-plant transmission. Evolutionary studies show that the vector is transmitted by specific biotype. De Barro et al. demarcated B. tabaci into welldefined groups containing 24 species having indistinguishable complexity [14]. Due to natural evolutionary trade and dispersal level, different biotypes of $B$. tabaci were no longer constraint to a particular geographical area. For instance, B. tabaci introduce in North Bengal reach the periphery of northeastern states of India and Indo Burma border. More futuristic approach is needed to establish all the proposed 24 species in exploring begomovirus and the vector itself.

\subsubsection{Infection}

From phloem cell to mesophyll cell through vascular tissue, the transmissions foster the feeding pattern of virulence whitefly. Encoding the viral particle in the cells, uncoated viral genome onset the replication. Initiation, elongation, and termination complete the whole replication process. However, the presence of host factor is responsible for the execution of all the above three processes. Rep protein is the sole factor viral DNA replication. Binding of Rep protein is the sole factor in viral DNA replication. Binding of Rep to IR creates a nick at the conserved sequence, thereby producing a replication fork in synchronize with the host factor RF-C, PCNA, RPA, RAD54, SCE 1, and DNA polymerase initiating RCR [15]. At the 3'OH end produce by Rep, elongation begins with helicase action (Rep). In case of termination process, Rep cuts and relegates the ssDNA making it circular.

\subsection{Viral Detection}

The most established techniques based on PCR, viral serology, tissue blot immunoassay, and tissue blot hybridization. The microplate method of ELISA has been employed for routine testing of plant virus and many variants of these assays have been developed. Begomovirus genome could also track down using blot immunoassay method. Serology based detection was less promising for virus with poor immunogenicity or showing diverse serological variation. Probe based on conserved genomic sequence has been engaged successfully in detection [16]. Due to evolutionary changes and genetic drift of viral genome, the prevailing technique became obsolete and inaccurate in some cases. Many laboratories used high fidelity phi 29 DNA polymerase along with random hexamer in detecting the viral genome [17]. Highly selective, targeted, and more rational methodology like Artificial Intelligence-based viral detection would be a revolutionary approach acclimatizing and adapting the fastgrowing genetic diversity and evolutionary changes of begomovirus.

\subsection{Viral Pathogenicity, Pugnacity Aspects, and Antagonistic Aggressive Strategies}

Lacking the adaptive immune system plant response to viral attacks rely on the primal RNA interference silencing pathways and hypersensitive response. RNAi gene silencing is a natural phenomenon in the plant system where siRNA or mi RNA recognizes the target RNA in sequence-specific manner and suppresses the translated approach [18]. As antagonistic strategies, viral-encoded factor suppresses RNAi signaling [19]. With this aspects, converting weak pathogen into virulent one, and in the absence of these attenuating the viral growth and thus known to be pathogenecity decisive.

\subsubsection{RNAi-assisted viral silencing}

RNAi technology is an evolutionary conserved mechanism gene regulation induced by small silencing RNA in sequence-specific manner. Some important concern of RNA interference was posttranslational gene regulation, transposon regulation and, most importantly defending the plant cells against pathogen [20]. The phenomena are important for both host and pathogen. Plant host concerns RNAi as an innate immune response against virus but the pathogen has the ability to disrupt the cell function, manipulating gene expression, and counter attacking the host defense system [21]. The phenomenon is well studied in plant cells. Plant genome whether DNA or RNA starts silencing through formation of double-stranded duplex with the help of Dicer. Dicer processed the double-stranded RNA generating siRNA duplex containing guide and passenger strand. RISCloading complex loads the duplex into RISC (RNA induced silencing complex). The passenger strand is later destroyed and guide strands direct RISC to the targeted viral genome. Evolutionary machinery gives virus to have suppressor counterattacking the RNA silencing signals of host plant [22]. Counter attacking through suppressor target mostly RISC and terminating silencing signals interfering with the

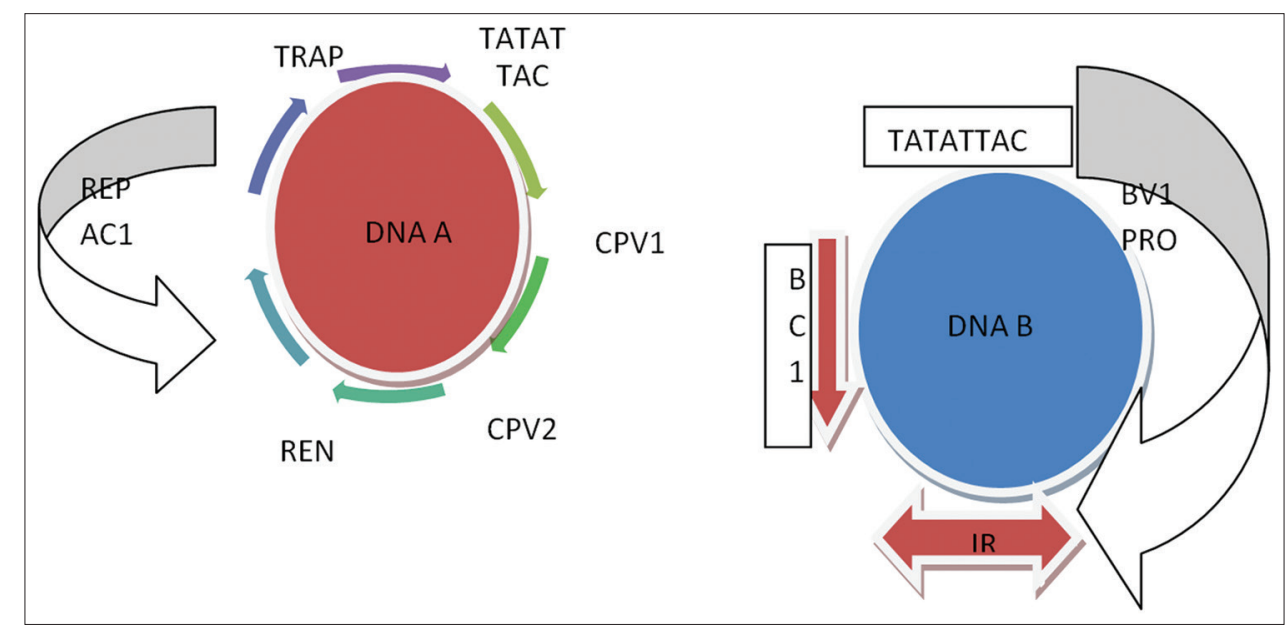

Figure 1: Organization of DNA A and DNA B component showing ORFs, other replication machinery proteins, and genes of complex begomovirus. 


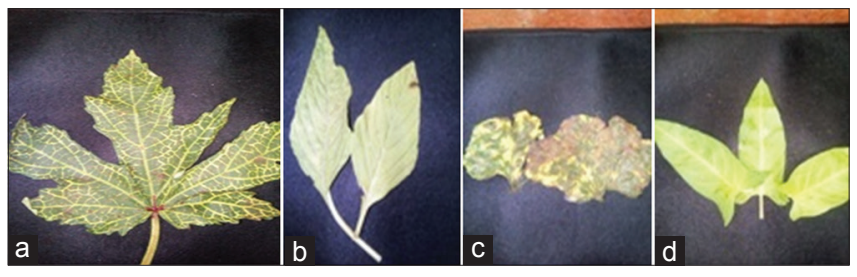

Figure 2: (a) Begomo infected Okra, (b) Amaranthus, (c) Cucurbitae, (d) Euphorbia.

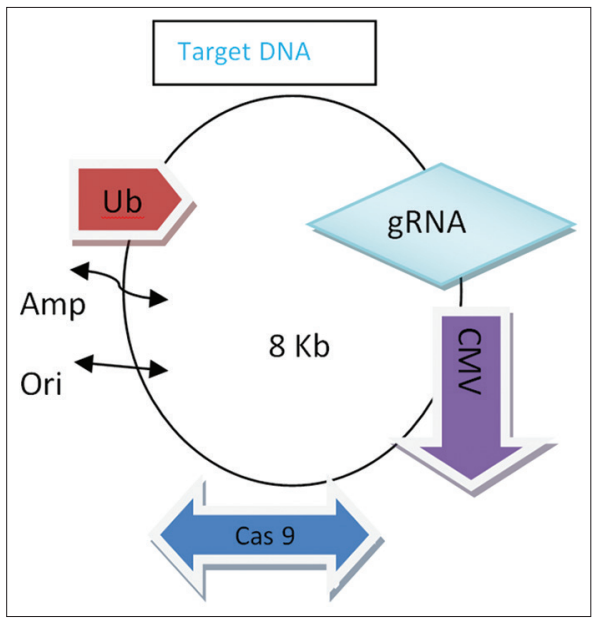

Figure 3: CRISPR/Cas vector construct for Begomo.

host silencing machinery. It was reported that Begomo have PTGS suppressor protein. For instance, Rep of alpha satellite and beta $\mathrm{C} 1$ of CLCuMB incorporating with begomovirus infecting cotton leaf curl disease $(\mathrm{CLCuD})$ have been reported to have vigorous silencing action (Amin et al., 2011a). Most viral encode suppressor protein interfere with the different reaction steps of RNAi pathway but not affecting the Dicer. Transgenic plant overexpressing miR167 seems developing dwarfed, enations, and swelling in vein which was classical hallmark of Begomo infection.

\subsection{Genetic Diversity of Begomovirus}

Due to population expansion, global human activity, newly develop agricultural practices, plant host and vector transportation, overwhelming climate change, and the diversity of viral strain attain a distinguished complexity. Higher the diversity, greater will be the number, ubiquity, occurrence, and worldwide distribution of the virus. Evidence-based report says that evolution of most Begomo found to coevolve from a common origin. Begomo show close and homogenous genome organization except the presence or absence of genetic factor, protein-encoding gene V2. Replication error, transcriptional or translational machinery malfunction, and recombination are responsible for genetic variation of most Begomo. Geographical distribution and barrier play crucial role in diversification of virus. The more complexity in diversity is observed in the center of origin comparing the peripheral part of genesis. Based on the phylogeny tree analysis from known sequence, eight well-defined geographical diversification centers were identified. Japan, Indian subcontinent, Mediterranean European region, Australia, Sub-Sahara Africa, South America, Central America, and China were eight investigated diversification center. In China and Indian subcontinent dominates most of the known DNA satellite and viral diversity. Africa and India having more or less similar subtropical and tropical climatic condition attain highest complexity in diversity. Among most plant infected by Begomo, tomato, bean, okra, Cucurbitae, tobacco, cotton, euphorbia, watermelon, etc., weed serves as potential dogma of recombination and acts as future reservoir of begomovirus. Genetic mutation, recombination, and trans-replication were also authenticated factor of the diverse expansion of Begomo.

\subsection{Productivity and Economic Loss by Different Strain}

The monitory and agro-economic loss is still a concern in modern agriculture. Different strains of geographical constraint affect diverse crops. Begomo affects most crops of India such as okra, brinjal, cassava, chili, cucurbits, legumes, papaya, potato, and tomato and huge loss in yield. ToLCV becomes a vital constraint in terms of productivity and economic loss of tomato in Gujarat. Nearly $40-90 \%$ of yield had been lost depending in terms of severity and stages of infection. $98 \%$ sharp increase in the incidence of ToLCD is being noted since the $1960 \mathrm{~s}$ with the implementation of high-yielding varieties in southern parts of Gujarat (Mahatna et al., 2017).

Experimental results indicate the establishment of negative correlation between the severity of symptoms and leaf area after 8-month plantations. $50-85 \%$ of positive correlation were observed between leaf area and dry weight of tuberous root, stems, etc. (Dengel et al., 1980). Soil profile, fertility, and other dynamic factors affecting the growth are directly proportional with the response to infection. The diminished root number, root size, and harvest index were the indicator of assessment shown in many local varieties of cassava (Otim Nape et al., 1992).

BYVMV, BHYBhV, BYVMaV, and OELCuV were the strain reported in Madurai, Bhubaneswar, Maharashtra, and Delhi, respectively (Fauquet et al., 2008). Tomato leaf curl New Delhi virus (ToLCNDV) was the strain showing positive relation infecting the brinjal (Pratap et al., 2011). The components of DNA A and DNA B were sequenced and analyzed later. Indian Cassava Mosaic Virus and Sri Lankan Cassava Mosaic virus are major contributors of Cassava infection in India (Saunders, 2002). BLAST analysis of ChiLCV shows the sequence similarity of Chili infecting Begomo of Lucknow and Multan, Pakistan (Shih et al., 2003). Cotton production was also severely constrained by CLCuD. CLCuD-associated begomoviruses (CABs) were the etiological viral agents (Sattar et al., 2005). Even Begomo affects the potato yield. Begomo causing severity in potato was observed in India. Nucleotide sequence analysis shows close relation of strains to ToLCNDV (Gawande et al., 2007). The disease also affects most of the leguminous crops such as mungbean, black gram, pigeon pea, moth bean, and common bean. The huge economical and productivity loss of black gram, mungbean, and soybean together were also justified [Tables 1 and 2].

\subsection{Knocking out the Begomovirus}

New technologies were still evolving and took time to establish and already shown promising. Advance technologies such as CRISPR/ Cas9, Talens, and SmART pave the way successfully beam the virus. All the powerful technology and stylist genome editing tools show futuristic revolutionary approach in knocking out most plant pathogen. CRISPR/Cas 9-based genome editing was grooved from adaptive immune response of most prokaryote [23]. The technology is highly efficient and the CRISPR Cas9 vector shows potential comfort with plant system but low editing efficiency [24]. CRISPR Cas9 is RNAmediated nuclease system and RNA will help in guiding the nuclease 
Table 1: Comparative genetic variant diversity of most begomovirus infected plant geographically.

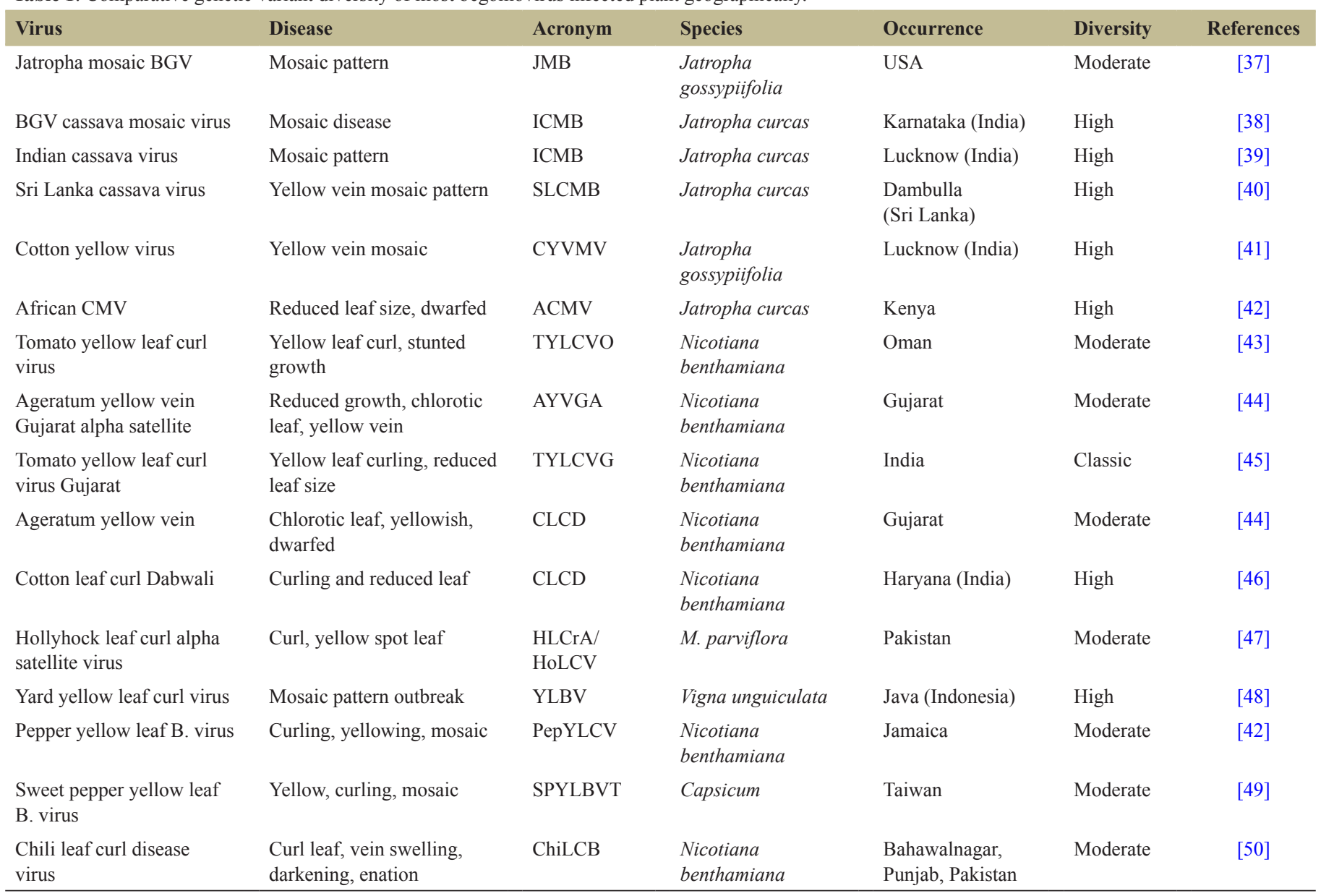

Table 2: CRISPR/Cas9 editing possible competent applications.

\begin{tabular}{|c|c|c|c|c|c|c|}
\hline $\begin{array}{l}\text { Targeted plant } \\
\text { species infected by } \\
\text { Begomo }\end{array}$ & $\begin{array}{l}\text { Transformation } \\
\text { method }\end{array}$ & $\begin{array}{l}\text { Disease-associated } \\
\text { promoter }\end{array}$ & $\begin{array}{l}\text { SgRNA } \\
\text { promoter }\end{array}$ & Collective strategies & $\begin{array}{l}\text { Possible editing } \\
\text { efficiency }\end{array}$ & References \\
\hline $\begin{array}{l}\text { Jatropha } \\
\text { Euphorbiaceae }\end{array}$ & $\begin{array}{l}\text { Agrobacterium/ } \\
\text { particle bombardment }\end{array}$ & $\mathrm{REP} / \mathrm{AC} 3$ & Atu6 & $\begin{array}{l}\text { Golden gate/ } \\
\text { sequential cloning }\end{array}$ & $50-60 \%$ mutation & [34] \\
\hline Tomato & Agrobacterium & $\mathrm{Rep} / \mathrm{Cp} / \mathrm{bc} 1$ & Atu626 & $\begin{array}{l}\text { Golden gate/Gibson } \\
\text { assembly }\end{array}$ & $20-30 \%$ & {$[35]$} \\
\hline $\begin{array}{l}\text { Nicotiana } \\
\text { benthamiana }\end{array}$ & $\begin{array}{l}\text { Agrobacterium/agro } \\
\text { filtration }\end{array}$ & $\mathrm{Rep} / \mathrm{cp} / \mathrm{nsp}$ & OSU6a & $\begin{array}{l}\text { Sequential cloning/ } \\
\text { golden gate }\end{array}$ & $6.7 \%$ & [33] \\
\hline Cotton & Agrobacterium & $\mathrm{Rep} / \mathrm{cp} / \mathrm{bc}$ & Zmu6 & Golden gate & $23 \%$ & [30] \\
\hline Long beans & Agrobacterium & $\mathrm{CP} / \mathrm{Rep} / \mathrm{bc} 1 / \mathrm{NSP}$ & OSU6a & $\begin{array}{l}\text { Golden gate/Gibson } \\
\text { assembly }\end{array}$ & $30.6 \%$ & [32] \\
\hline Cucurbitae & Agrobacterium/ & $\operatorname{Rep} / A c 4 / c p$ & OSU6b/AtU629 & $\begin{array}{l}\text { Golden gate/Gibson } \\
\text { assembly }\end{array}$ & $13-67 \%$ & [36] \\
\hline
\end{tabular}

(breakdown of nucleotide). Cas9 is bacterial based system fighting the virus. Cas 9 is short RNA with 20-30 nucleotides long. When the bacterium detects the presence of viral DNA, it produces two types of short RNA, one of which contains the sequence that matches that of the invading virus. These two RNA form a complex with protein called Cas9. Cas9 is nuclease type of enzyme that cut the DNA. When matching sequence known as guide RNA found its target within the viral genome, Cas9 cuts the target DNA, disabling the virus. It can cut any DNA sequence at a precisely chosen location by changing the guide RNA to match the target. This system could also be done in the nucleus of living cells. Once inside the nucleus, the resulting complex will lock into the short sequence known as PAM. Cas9 will unzip the DNA and matches its target RNA.

\subsection{CRISPR/Cas Vector System for Plant Infected with Begomovirus}

SgRNA expression cassette with 90 nucleotide containing the 20 nucleotide target DNA sequence will concern as guide RNA in sgRNA-Cas9 complex. SgRNA expression was driven by the 
U3/U6 promoter [25]. Targeted expression cassette sequence with SgRNA could be obtained from PCR. Ubiquitin constitutive promoter or CaMV promoter (CaMV35S) will suffice in driven Cas9 complex. Editing efficiency is more in case of constitutive ubiquitin promoter [26]. For in vivo genome editing of Begomo constructed vector conveying SgRNA expression, cassette and casa9 must deliver in plant cells. Using immature embryo and biolistic transformation could integrate Cas9 and SgRNA expression construct in host genome. Agrobacterium-mediated transformation construct of Cas 9 and sgRNA expression cassette is the most efficient one in plant system and is reported in rice, maize, tobacco, tomato, potato, etc. [27]. Golden gate cloning method uses Bsal endonuclease generating highly compatible, non-palindromic sticky end and could ligate multiple fragment with homologous termini by the action of T5 exonuclease [28]. Many reporter genes such as GFP, YFP, RFP, and Lux were used as beacon of editing phase [29]. Targeted mutation can also be confirmed by visualizing destroyed targeted restriction enzyme site before or after the onset of PCR amplification. Single-strand conformation polymorphism assists the detection of mutation by CRISPR Cas9. Molecular-assisted technology such as high-resolution melting, high throughout melting, and Sanger sequencing detects the mutation or editing events [30-32].

\section{CONCLUSION AND FUTURE INTEREST}

New variant of Begomo is still evolving. Because of the genetic mutation, recombination, current cropping pattern, global agro economic trade policies and climate change, novel Begomo mutant unfold. Many ornamental, medicinal, and agro important plants were affected and thus rational advance management strategies become global urgencies. Plantation of crop has been increased dramatically worldwide. Begomo bug drastically hinders crop yield, agriculture sector which, in turn, harms the livelihood of farmer and global agroeconomy. With the seasonal agricultural practices exploring the new scientific method to meet the demand of the expanding population, for improving food security, we thus need a commendable force of strategic Begomo management. Begomo and its ability of molecular trafficking directly from early endosome to plasma membrane and thus reached the hemolymph of whitefly. With this interest, futuristic identification and detection of molecular signals or genes controlling the traffic would pave the way toward the novel target controlling the viral replication in pioneering agricultural approach. Mixed cropping pattern prevalent in India, polyphagous nature of vector, overlapping host range, suitable weather supports the survival and prevalence of whitefly. Recombination is one of the genetic elements which foster the evolution of diverse strain in India. The attempt to suppress the Begomo with the stylist editing tool such as TALENS and CRISPR will foster a healthier environment in modern agriculture. To monitor and control the agro-economic loss, a viable option for strategic Begomo management needs to overcome most agricultural snag, hindrance so that it could become a healthier and productive agro-economy and a promising revolution in the science of agriculture will unfold.

\section{REFERENCES}

1. Yadav P, Suyal G, Mukherjee SK. Begomo virus DNA replication and pathogenecity. Curr Sci 2010;98:360-8.

2. Lecoq H, Desbiez C. Virus and virus diseases of vegetables in the Mediterranean basin. Adv Virus Res 2012;101:243-9.

3. Idris AM, Shahid MS, Briddon RW, Khan AJ, Zhu JK, Brown JK, et al. An unusual alphasatellite associated with monopartite begomoviruses attenuates symptoms and reduces betasatellite accumulation. J Gen Virol 2011;92:706-17.

4. Kumar RV, Singh AK, Singh AK, Yadav T, Basu S, Kushwaha N, et al. Complexity of Begomovirus and betasatellite populations associated with chilli leaf curl disease in India. J Gen Virol 2015;96:3143-58.

5. Rishi N. Significant plant diseases in India and glimpse of modern disease management technology. J Gen Plant Pathol 2008;75:1-18.

6. Bisaro DM. Germinivirus DNA replication. Cold Spring Harb Monogr Arch 2001;30:833-54.

7. Arguello-Astorga G, Ascencio-Ibanez T, Dallas MB, Orozco BM, Bowden H. High frequency reversion of Gemini virus replication protein mutants during infection. J Virol 2007;81:11005-15.

8. Leke WN, Mignouna DB, Brown JK, Kvarnheden A. Begomo disease complex: Emerging threats to vegetable production systems of West and Central Africa. Agric Food Secur 2015;4:1-14.

9. Briddon RW, Bull SE, Amin I, Idris AM, Mansoor S, Bedford ID, et al. Diversity of DNA beta, a satellite molecule associated with some monopartite begomoviruses. Virology 2003;312:106-21.

10. Bisaro DM. Silencing suppression by geminivirus proteins. Virology 2006;344:158-68.

11. Khan AJ, Al Saddy NA, Al-Mahruki MS, Al Oufi M, Ali M, Al-Subhi M. Molecular characterisation of Begomo infecting sweet pepper in Oman. Indian J Biotechnol 2007;6:45-51.

12. Singh DK, Karjee S, Malik PS, Islam N, Mukherjee SK. DNA replication and pathogenecity of MYMIV. Commun Curr Res Educ Top Trends Appl Microbiol 2007;23:101-10.

13. Mayo MA, Pringle CR. Virus taxonomy. J Gen Virol 1997;7514

14. De Barro PJ, Liu SS, Boykin LM, Dinsdale AB. Bemisia tabaci: A statement of species status. Annu Rev Entomol 2011;56:1-9.

15. Snehi SK, Prihor SS, Gupta G, Singh V, Raj SK, Prasad V. The current status of new emerging begomovirus disease on Jatropha species from India. J Plant Pathol Microbiol 2016;7:1-8.

16. Srivastava A, Kumar S, Jaidi M, Raj SK. Molecular characterization of a new Begomovirus associated with leaf yellow mosaic disease of Jatropha curcas in India. Arch Virol 2015;160:1359-62.

17. Brown JK. The molecular epidemiology of Begomovirus. In: Trends in Plant Virology. New York: The Haworth Press; 2001. p. 279-316.

18. Obbard DJ, Gordon KH, Buck AH, Jiggins FM. The evolution of RNAi as a defence against viruses and transposable elements. Philos Trans R Soc Lond B Biol Sci 2009;364:99-115.

19. Tomás DM, Cañizares MC, Abad J, Fernández-Muñoz R, Moriones E. Resistance to tomato yellow leaf curl virus accumulation in the tomato wild relative Solanum habrochaites associated with the C4 viral protein. Mol Plant Microbe Interact 2011;24:849-61.

20. Trinks D, Rajeswaran R, Shivaprasad PV, Akbergenov R, Oakeley EJ, Veluthambi K, et al. Suppression of RNA silencing by a geminivirus nuclear protein, $\mathrm{AC} 2$, correlates with transactivation of host genes. J Virol 2005;79:2517-27.

21. Van Den Bosch F, Akudibilah G, Steal S, Jeger M. Host resistance and evolutionary response of plant virus. J Appl Ecol 2006;43:506-15.

22. Vanitharani R, Chellappan P, Fauquet CM. Geminiviruses and RNA silencing. Trends Plant Sci 2005;10:144-51.

23. Ma X, Zhu Q, Chen Y, Liu YG. CRISPR/Cas9 platforms for genome editing in plants: Developments and applications. Mol Plant 2016;9:961-74.

24. Lei Y, Lu L, Liu HY, Li S, Xing F, Chen LL, et al. CRISPR-P: A web tool for synthetic single-guide RNA design of CRISPR-system in plants. Mol Plant 2014;7:1494-6.

25. Jiang W, Zhou H, Bi H, Fromm M, Yang B, Weeks DP, et al. Demonstration of CRISPR/Cas9/sgRNA-mediated targeted gene modification in arabidopsis, tobacco, sorghum and rice. Nucleic Acids Res 2013;41:e188.

26. Zhou X, Jacobs TB, Xue LJ, Harding SA, Tsai CJ. Exploiting SNPs for biallelic CRISPR mutations in the outcrossing woody perennial populus reveals 4-coumarate: CoA ligase specificity and redundancy. 
New Phytol 2015;208:298-301.

27. Svitashev S, Young JK, Schwartz C, Gao H, Falco SC, Cigan AM, et al. Targeted mutagenesis, precise gene editing, and site-specific gene insertion in maize using cas9 and guide RNA. Plant Physiol 2015;169:931-45.

28. Engler C, Kandzia R, Marillonnet S. A one pot, one step, precision cloning method with high throughput capability. PLoS One 2008;3:e3647.

29. Jiang W, Yang B, Weeks DP. Efficient CRISPR/Cas9-mediated gene editing in Arabidopsis thaliana and inheritance of modified genes in the T2 and T3 generations. PLoS One 2014;9:e99225.

30. Fauser F, Schiml S, Puchta H. Both CRISPR/Cas-based nucleases and nickases can be used efficiently for genome engineering in Arabidopsis thaliana. Plant J 2014;79:348-59.

31. Shan Q, Wang Y, Li J, Zhang Y, Chen K, Liang Z, et al. Targeted genome modification of crop plants using a CRISPR-cas system. Nat Biotechnol 2013;31:686-8.

32. Dahlem TJ, Hoshijima K, Jurynec MJ, Gunther D, Starker CG, Locke AS, et al. Simple methods for generating and detecting locusspecific mutations induced with TALENs in the zebrafish genome. PLoS Genet 2012;8:e1002861.

33. Nekrasov V, Staskawicz B, Weigel D, Jones JD, Kamoun S. Targeted mutagenesis in the model plant Nicotiana benthamiana using cas9 RNA-guided endonuclease. Nat Biotechnol 2013;31:691-3.

34. Ma X, Zhang Q, Zhu Q, Liu W, Chen Y, Qiu R, et al. A robust CRISPR/ Cas9 system for convenient, high-efficiency multiplex genome editing in monocot and dicot plants. Mol Plant 2015;8:1274-84.

35. Brooks C, Nekrasov V, Lippman ZB, Van Eck J. Efficient gene editing in tomato in the first generation using the clustered regularly interspaced short palindromic repeats/CRISPR-associated9 system. Plant Physiol 2014;166:1292-7.

36. Osakabe Y, Osakabe K. Genome editing with engineered nucleases in plants. Plant Cell Physiol 2015;56:389-400.

37. Kim KS, Bird J, Martin EM, Escudero J. Ultra structural studies of Jatropha gossypifolia infected with Jatropha mosaic virus, a whitely transmitted geminivirus. Phytopathology 2006;76:80.

38. Narayana AD, Rangaswamy KT, Shankarappa KS, Maruthi MN, Laksminarayana CN, Rekha AR, et al. District Begomovirus closely related to cassava mosaic virus's cause Indian Jatropha mosaic disease. Int J Virol 2007;3:1-11.

39. Raj SK, Snehi SK, Kumar S, Khan MS, Pathre U. First molecular identification of a begomovirus in India that is closely related to cassava mosaic virus and causes mosaic and stunting of Jatropha curcas L. Australas Plant Dis Notes 2008;3:69-71.
40. Snehi SK, Khan MS, Raj SK, Prasad V. Complete nucleotide sequence of croton yellow vein mosaic virus and DNA- $\beta$ associated with yellow vein mosaic disease of Jatropha gossypifolia in India. Virus Genes 2011;43:93-101.

41. Ramkat RC, Alberto C, Fatemeh M, Margit L. Occurrence of African cassava mosaic virus (ACMV) and East African cassava mosaic virus-Uganda (EACMV-UG) in Jatropha curcas. BMC Proc 2011;5:93

42. Royce ME, Wernecke ME, McLaughlin WA, Nakhla MK, Maxwell DP. Tomato dwarf leaf curl virus, a new bipartite geminivirus associated with tomatoes and peppers in Jamaica and mixed infection with tomato leaf curl virus. Plant Pathol 2009;48:370-8.

43. Khan AJ, Idris AM, Al-Saady NA, Al-Mahruki MS, Al-Subhi AM, Brown JK, et al. A divergent isolate of tomato yellow leaf curl virus from Oman with an associated DNA beta satellite: An evolutionary link between Asian and the Middle Eastern virus-satellite complexes. Virus Genes 2008;36:169-76.

44. Saunders K, Bedford ID, Briddon RW, Markham PG, Wong SM, Stanley J, et al. A unique virus complex causes ageratum yellow vein disease. Proc Natl Acad Sci U S A 2000;97:6890-5.

45. Venthana M, Mahatna L, Ghavariya TV, Saranya R. Molecular characterization of tomato leaf curl virus in South Gujarat, India. Int J Curr Microbial App Sci 2017;6:437-81.

46. Sattar MN, Kvarnheden A, Saeed M, Briddon RW. Cotton leaf curl disease-an emerging threat to cotton production worldwide. J Gen Virol 2013;94:695-710.

47. Sattar N, Qurashi F, Iqbal Z, Haider MS. Molecular characterization of hollyhock leaf curl virus and associated DNA-satellites infecting Malva parviflora in Pakistan. Can J Plant Pathol 2017;21:212-7.

48. Chiemsombat P, Srikamphung B, Yule S. Begomovirus associated to pepper yellow leaf curl disease in Thailand. Open Access J Agric Res 2018;3:123-6

49. Tsaiab WS, Shiha SL, Kenyona L, Greene SK, Janb FJ. Temporal distribution and pathogenecity of the predominant tomato-infecting begomovirus in Taiwan. Plant Pathol 2011;60:787-99.

50. Sanayake DM, Mandal B, Lodha S, Verma A. First report of chilli leaf curl virus affecting chilli in India. Plant Pathol 2007;56:343.

How to cite this article:

Sharma HJ, Sharma SK, Singh NB. Genome complexity of begomovirus

disease and a concern in agro-economic loss. J App Biol Biotech.

2019;7(03):78-83. DOI: 10.7324/JABB.2019.70314 